\author{
ZBIGNIEW ZAGÓRSKI*1, MONIKA KISIEL², AGNIESZKA KUŚMIERZ ${ }^{2}$ \\ ${ }^{1}$ Warsaw University of Life Sciences - SGGW, Faculty of Agriculture and Biology, Department of Soil Environment Sciences \\ Nowoursynowska Str. 159, 02-776 Warsaw, Poland \\ ${ }^{2}$ Cardinal Stefan Wyszyński University in Warsaw, Faculty of Biology and Environmental Sciences, \\ Department of Environmental Engineering, Wóycickiego Str. 1/3, 01-938 Warsaw, Poland
}

\title{
Selected properties and systematic position of soils developed from red sandstones and clays of the Lower Triassic Buntsandstein in the NW part of the Holy Cross Mountains (Poland)
}

\begin{abstract}
The aim of the study was to compare the properties of soils developed from the Lower Triassic Buntsandstein sediments in the north-western part of the Holy Cross Mountains (Poland). These are deposits of continental genesis and unique features such as red beds. Two representative soil pedons - the Bartków profile (pBK) developed from clay and the Góra Czerwona profile (pGC) developed from sandstone were selected for detailed analyzes. The morphology of profiles, their micromorphological features, mineralogical composition, and physico-chemical properties were examined. Most of the properties of the soils are a consequence of the original parent rock lithology. A specific feature of the morphology of the soils are the presence of red color (about 10R by the Munsell color scale) related to the presence of hematite. As shown by the XRD data, hematite is not the product of the current soilforming processes, but it is a lithogenic component, which was inherited from the parent rock. Under the influence of climatic factors primary rock structure has been transformed into a new pedogenic one. Soils developed from clays have a characteristic angular blocky structure. Micromorphological analysis showed that an important role in the formation of soil structure involves geogenic susceptibility of Triassic clays to specific cuboid disintegration. This is indicated by the pore system of planes as an orthogonal nets visible in thin section. The soils developed from sandstone have a weak (unstable) subangular blocky structure. The main reason is the insufficient dispersion of the clay-ferruginous fraction from the sandstone matrix. Microscopic observations indicate that fine factions occurs as loose microaggregates, which results in a feature that smaller rock fragments and individual quartz grains are not bonded into soil aggregates. The studied soils are characterized by specific physical-chemical properties. Some of them strongly depend on the mineralogical properties of the soil substrate. Strong acidity ( $\mathrm{pH} 3-4$ ) and a very low content of base cations (below $1.0 \mathrm{cmol}_{(+)} \mathrm{kg}^{-1}$ ) are due to a lack of carbonate minerals in sandstones and weak weathering of aluminium silicate. High exchangeable $\mathrm{Al}$ content in clay $\left(16.5 \mathrm{cmol}_{(+)} \mathrm{kg}^{-1}\right)$ should be related to the geochemical properties of the red bed-type rocks such as the Lower Triassic Buntsandstein deposits. Soils developed from the Lower Triassic Buntsandstein clays have a sequence of genetic horizons: $\mathrm{Ap}, \mathrm{Bw}, \mathrm{Bw} / \mathrm{C}, \mathrm{C}$ and fulfill the criteria assigned to dystrophic typical brown soils (BDt) in the Polish Soil Classification (PSC 2011), whereas in the WRB they were classified as Endoeutric Chromic Cambisols (Loamic). Soils developed from the Lower Triassic Buntsandstein red sandstone can be classified as dystrophic humus brown soil (BDpr) in the PSC (2011). Within the WRB classification that soil can be assigned to Epidystric Chromic Endoleptic Cambisols.
\end{abstract}

Keywords: Triassic (Buntsandstein), red clays and sandstones, soil micromorphology, soil mineralogy, soil properties, Holy Cross Mountains, Poland

\section{INTRODUCTION}

A common problem in soils strongly influenced by the specific character of the parent rock is the correct description of the morphological features and the interpretation of the soil properties. Such soils are, for example, soils developed from rocks referred to as red beds. Red beds are sediments or rock formations that have formed in the geological past in specific terrestrial conditions (Turner 1980). At present, they crop on the surface in many parts of the world, in diverse climate zones and variable geomorphological conditions. Soils developed from such rocks are difficult to classify using conventional diagnostic pro- xies (Vodyanitskii et al. 2003, Lesovaya et al. 2005, Hanlie et al. 2010).

The Holy Cross Mountains represent one of the very few places in central Poland with outcrops of older rocks on the surface that can be referred to red beds (Sokołowski et al. 1973). They include the Lower Triassic Buntsandstein deposits. In the NW part of the Holy Cross Mountains, these rocks are exposed on a large area as compact covers or small outcrops in the vicinity of rocks of different origin or age, e.g. among Quaternary sediments or Devonian limestones (Filonowicz 1973, 1979). Usually they are developed as red sandstones, clays or claystones. The area covered by Lower Triassic rocks is very intere- 
sting in terms of soil science. Lithological uniqueness of the rocks results in soils that have features and properties unknown in other, genetically comparable soils, as shown by the studies of Szafranek (1989, 1990), Zagórski and Brzychcy (2009) and Zagórski and Kisiel $(2010,2014)$. The red colour of the rock substrate 'masks' some morphological features of the soils, particularly those formed as an effect of pedogenic processes (Zagórski and Kaczorek 2002). Moreover, specific physical and chemical properties of these soils distinguish them from soils developed from sandstones and claystones of other geological formations, e.g. flysch rocks (Szafranek and Skłodowski 2006, Kacprzak et al. 2015). According to Skłodowski and Maciejewska (1986), this may be the result of the mineralogical composition of the soil substrate derived from the parent rock.

The studies focused on the comparison of the properties of soils developed from rocks representing two main lithological members of the Lower Triassic in the NW part of the Holy Cross Mountains, i.e. sandstones and claystones. The obtained data allowed for determination of the origin and classification of these soils according to the PSC (2011) and WRB (IUSS Working Group WRB 2015).

\section{MATERIALS AND METHODS}

\section{Geological setting and location of the study area}

The studies were conducted in the north-western part of the Holy Cross Mountains, central Poland. Triassic and Jurassic rocks of the Mesozoic margin of the Holy Cross Mountains crop out in the area. The complex structural setting, variety of sediments and geomorphological transformations in the Quaternary have resulted in a diversified landscape of the area. Narrow, parallel ridges and isolated small elevations, surrounded by valleys with present-day streams, are a characteristic feature of that area (Klatka 1965, Lindner 1971). The investigations focused on outcrops of Lower Triassic Buntsandstein deposits building the topmost parts of the elevations. Depending on the primary palaeogeographic setting, the deposits are developed as red clays, claystones, mudstones or sandstones (Filonowicz 1973, 1979). Lithological variability is often local in character and typical of continental sequences (Senkowiczowa and Ślączka 1962, Senkowiczowa 1966). Hematite is an important mineral component of the Buntsandstein sediments in the Holy Cross Mountains (Barczuk 1979). Inferruginous sandstones, this mineral is part of the matrix, and in clays, claystones and mudstones it is a component of the clay fraction. Locally, it forms macroscopic concentrations in the form of concretions or pseudoolites (Kleczkowski 1970).

Soils developed from two characteristic Lower Triassic rock units - red clays and red sandstones were subject to the analyses. Two representative soil pedons were selected: Góra Czerwona (profile pGC) and Bartków (profile pBK) (Fig. 1). Profile pGC represents forest soil developed on ferruginous sandstones exposed within the culmination of a distinct hill at $350 \mathrm{~m}$ a.s.l. (Góra Czerwona), located ca. $6 \mathrm{~km}$ to the west of Suchedniów town. The area surrounding the profile is flat, without significant signs of erosion, covered by a forest with the dominant European silver fir (Abies alba Mill.) and the subordinate European beech (Fagus silvatica L.) and European oak (Quercus robur L.).

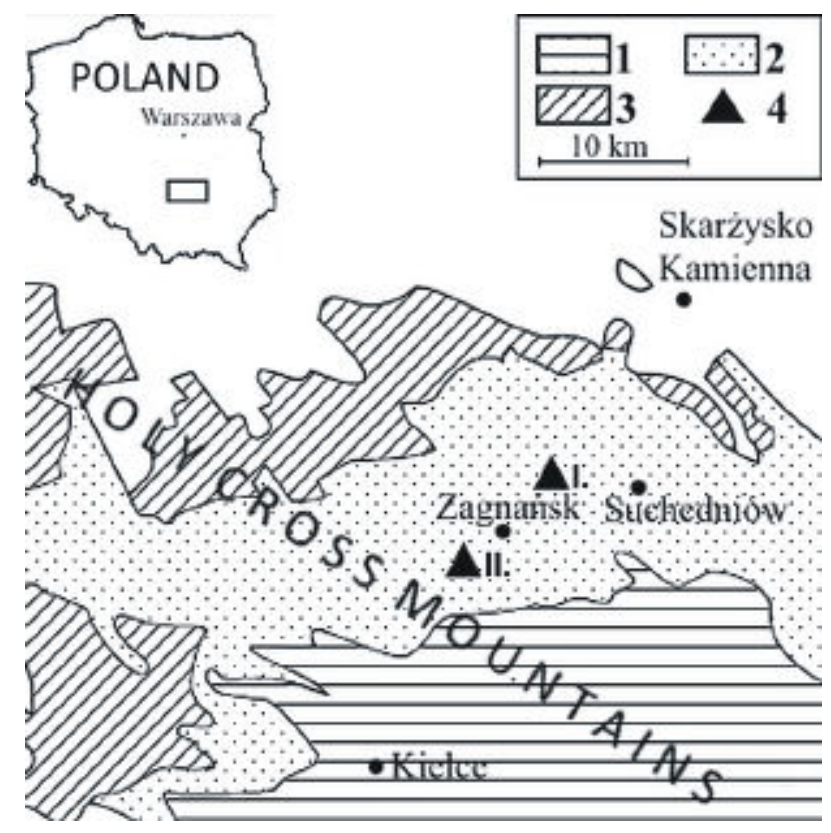

FIGURE 1. Geological sketch map of the NW Holy Cross Mountains and localization of the investigated soil pedons: I pGC (Góra Czerwona), II - pBK (Bartków): 1 - Paleozoic basement, 2 - Lower Triassic Buntsandstein, 3 - Middle and Upper Triassic, 4 - Soil pedons

Profile $\mathrm{pBK}$ is situated in the eastern part of a vast hill at ca. $330 \mathrm{~m}$ a.s.l. composed of clay rocks, mainly clays with claystone and mudstone interbeds. The soil profile was localized on arable ground in Bartków village, situated about $2 \mathrm{~km}$ to the west of Zagnańsk village.

\section{Methods}

The description of the soil profiles was made according to the requirements of the PSSS (Kabała et al. 2014) and IUSS (Jahn et al. 2006). Soil colour was determined according to the RSSCC catalogue 
(Oyama and Takehara 1970). Micromorphological analyses were made in thin sections using an Olympus BX41 polarizing microscope. Interpretation of micromorphological features followed the guidelines of Brewer (1964), Bullock et al. (1985), Stoops (2003), and Stoops et al. (2010). Mineralogical analyses were made for all genetic horizons. The $<0.1 \mathrm{~mm}$ fractions were tested in ground samples using X-ray diffractometry conducted on D-5005 Brucker/AXS equipment. Qualitative identification of particular minerals was based on $d h k l$ values of characteristic reflexes compared with the standard (Brindley and Brown 1980, Cornell and Schwertmann 2006).

Determinations of the basic soil properties were made according to the standards used in soil science (Karczewska and Kabała 2005): particle-size distribution (PSD) using the Casagrande method in the modification of Prószyński, $\mathrm{pH}$ of soil in $\mathrm{H}_{2} \mathrm{O}$ and in $1 \mathrm{M} \mathrm{KCl}$ using the electrometric method, exchangeable hydrogen (Hex), exchangeable aluminium (Alex) using the Sokołow method $(1 \mathrm{M} \mathrm{KCl})$, potential acidity (Ha) using the Kappen method (extracting agent $\mathrm{Na}$ acetate), and exchangeable base cations $\mathrm{Ca}, \mathrm{Mg}$, $\mathrm{K}$, Na using ammonium acetate extraction at $\mathrm{pH}=7$. Total organic carbon (TOC) was determined using the TOC 5000A (Shimadzu) analyzer and total nitrogen $(\mathrm{Nt})$ was determined using the Kjeldahl method in a Kjeltec ${ }^{\circledR} 8100$ analyzer. The total iron content as $\mathrm{Fe}_{2} \mathrm{O}_{3}$ was determined using the XRF method in a WD-XRF analyzer, PW 2400 (Philips) at Central Chemical Laboratory, Polish Geological Institute (CCHL PIG)

\section{RESULTS}

\section{Morphology of the soil profiles}

The selected soil profiles are characterized by specific morphological properties. The main feature is the red colour of the genetic horizons, in the range of about 10R according to the RSSCC (Oyama and Takehara 1970) colour charts. The general views of the soil profiles is presented in Figure 2.

Macroscopic features of the soils studied are described below.

\section{Pedon Bartków (profile pBK)}

Horizon Ap, 0-20 cm

Very little skeleton sandy loam, very dark reddish brown 10R 2/3 Moderate subangular blocky structure, crumbly in places. The fabric weakly concise. Single pebbles and gravels with a diameter ca. $2-3 \mathrm{~cm}$. Few roots of crops. Fresh moist. Slightly acid soil reaction. Distinct transition to the horizon below, wavy boundary.

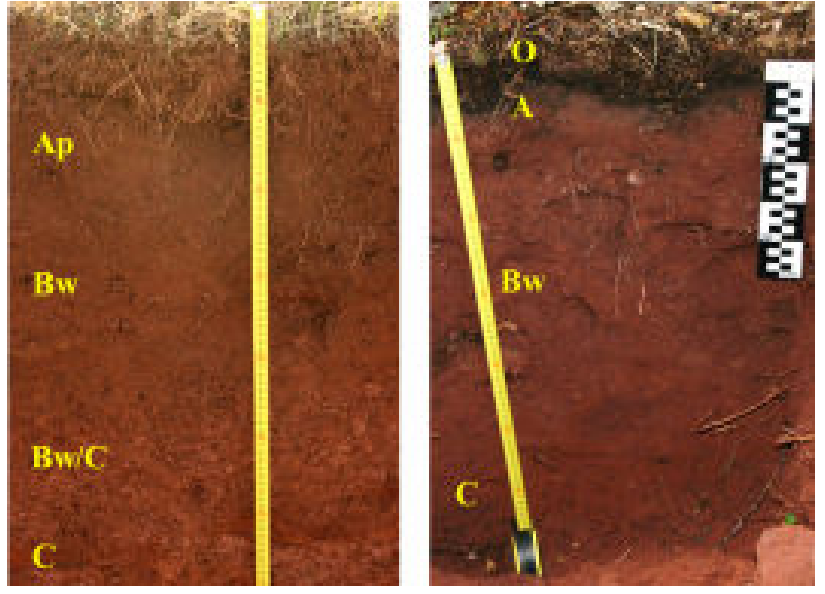

FIGURE 2. View of soil pedons developed from Lower Triassic Buntsandstein sediments: a - Pedon Bartków (pBK) developed from red clays (left); $b$ - Pedon Góra Czerwona (pGC) developed from red sandstone (right)

\section{Horizon Bw, 20-45 cm}

Very little skeleton loam, red $10 \mathrm{R} 4 / 6$, in some places a little bit brighter spots dull reddish orange 10R 6/4. Strong subangular blocky structure, concise fabric. Fresh moist. Slightly acid soil reaction. Gradual transition to the horizon below, irregular boundary.

\section{Horizon Bw/C, 45-60 cm}

Loam (L), red 10R 5/8. Strong angular blocky structure, locally prismatic. The concise fabric. Fresh moist. Slightly acid soil reaction. Gradual transition to the horizon below, blurred boundary.

Horizon C, depth $>60 \mathrm{~cm}$

Beds of Lower Triassic Buntsandstein clays. Clay loam (CL), red 10R 4/8. Compact fabric, in some places the clay forms prismatic pieces. Fresh moist. Acid soil reaction.

\section{Pedon Góra Czerwona (profile pGC)}

Horizon $\mathrm{O}, 5-0 \mathrm{~cm}$

Coniferous-deciduous forest litter.

Horizon A, 0-10 cm

Little skeleton loamy sand, (LS), very dark reddish brown 10R 2/2. Moder-mull humus type. Single grain structure, crumbling in places. The weakly concise fabric. Single sharp edge pieces of ferriferous sandstone with a diameter of 3-15 cm. Numerous roots of trees and shrubs. Fresh moist. Strongly acid soil reaction. Clear transition to the horizon below, wavy boundary.

Horizon Bw, 10-45 cm

Cobbly loamy sand (SLcb). The color ranges from dark red $10 \mathrm{R} 3 / 6$ to red $10 \mathrm{R} 4 / 6$. The structure is diverse: in the upper part is single grain, but deeper is weak (unstable) subangular blocky. Moderately concise fabric. Numerous tree roots and sharp shards of ferriferous sandstones with a diameter 
greater than $7-18 \mathrm{~cm}$. Fresh moist. Strongly acid soil reaction. Gradual transition to the horizon below, equal boundary.

Horizon $\mathrm{C},>45 \mathrm{~cm}$

Debris of Lower Triassic Buntsandstein sandstone. Very stony sand (SLcb2), red 10R 4/8. A large number of sharp edges, pieces of ferriferous sandstone with a diameter of $20 \mathrm{~cm}$. Fresh moist. Strongly acid soil reaction.

\section{Micromorphology}

Comparison of the internal structure of the studied soils was achieved by analyzing the micromorphology of the middle parts of the profiles - horizons Bw. The main micromorphological properties have been compared in Table 1.

The most significant micromorphological feature of the soil developed from claystones (pBK) is the characteristic subangular blocky structure. It was formed by the disintegration of the compact soil substrate into smaller fragments (aggregates) with dimensions even up to 20-30 mm, sharp edges and regular, subquadrangular or subrectangular contours. The individual units are separated by a narrow ( $2 \mathrm{~mm}$ width) free spaces of planar voids (planes) type. In a large observation field (Fig. 3), the planes form an orthogonal network. In some places, by increasing their dimensions the

TABLE 1. Main micromorphological features in the central parts (Bw horizons) of soil profiles developed from Lower Triassic sediments

\begin{tabular}{|c|c|c|c|c|}
\hline \multicolumn{3}{|l|}{ Feature } & $\begin{array}{l}\text { Soil pedon Bartków (pBK) } \\
\text { horizon Bw } \\
\text { depth } 20-40 \mathrm{~cm}\end{array}$ & $\begin{array}{l}\text { Soil pedon Góra Czerwona (pGC) } \\
\text { horizon Bw } \\
\text { depth } 10-45 \mathrm{~cm}\end{array}$ \\
\hline \multicolumn{3}{|l|}{ Soil Texture } & loam & sandy loam cobbly (SLcb1) \\
\hline \multicolumn{3}{|l|}{ Microstructure } & subangular blocky & intergrain mictroaggregate \\
\hline \multicolumn{3}{|l|}{ Porosity } & $\begin{array}{l}\text { planar voids (planes) }+++ \\
\text { chambers }++ \text { channels }+\end{array}$ & $\begin{array}{l}\text { simple packing voids }++ \\
\text { complex packing voids }+\end{array}$ \\
\hline \multirow[t]{3}{*}{ Groundmass } & Color & & $\begin{array}{l}\text { reddish brown, } \\
\text { same places light reddish gray }\end{array}$ & red, reddish brown \\
\hline & $\begin{array}{l}\text { Mineralogy/ } \\
\text { petrography }\end{array}$ & c (skeleton) & $\begin{array}{l}\text { fragments of claystone, single grains } \\
\text { of quartz, hematite concretions (ooides) }\end{array}$ & $\begin{array}{l}\text { shards of sandstone, grains of quartz, } \\
\text { hematite concretions (ooides) }\end{array}$ \\
\hline & & $\mathrm{f}$ (plasma) & clay minerals, quartz, hematite & clay minerals, hematite \\
\hline \multicolumn{3}{|c|}{$\mathrm{c} / \mathrm{f}$ related distribution } & open porphyric & enaulic \\
\hline \multicolumn{3}{|l|}{ b-Fabrics } & $\begin{array}{l}\text { undifferntiated b-fabric } \\
\text { staple speckled b-fabric }\end{array}$ & undifferntiated b-fabric \\
\hline \multicolumn{3}{|c|}{ Organic material } & pieces of roots & $\begin{array}{l}\text { organic amorphous aggregates and tissue } \\
\text { fragments plants }\end{array}$ \\
\hline \multicolumn{3}{|l|}{ Pedofeatures } & $\begin{array}{l}\text { depletion pedofeatures }(\mathrm{Fe})++ \text {, } \\
\text { clay coatings }+\end{array}$ & organic metatubules + \\
\hline
\end{tabular}

Frequency: very often +++ , often ++ , seldom + .

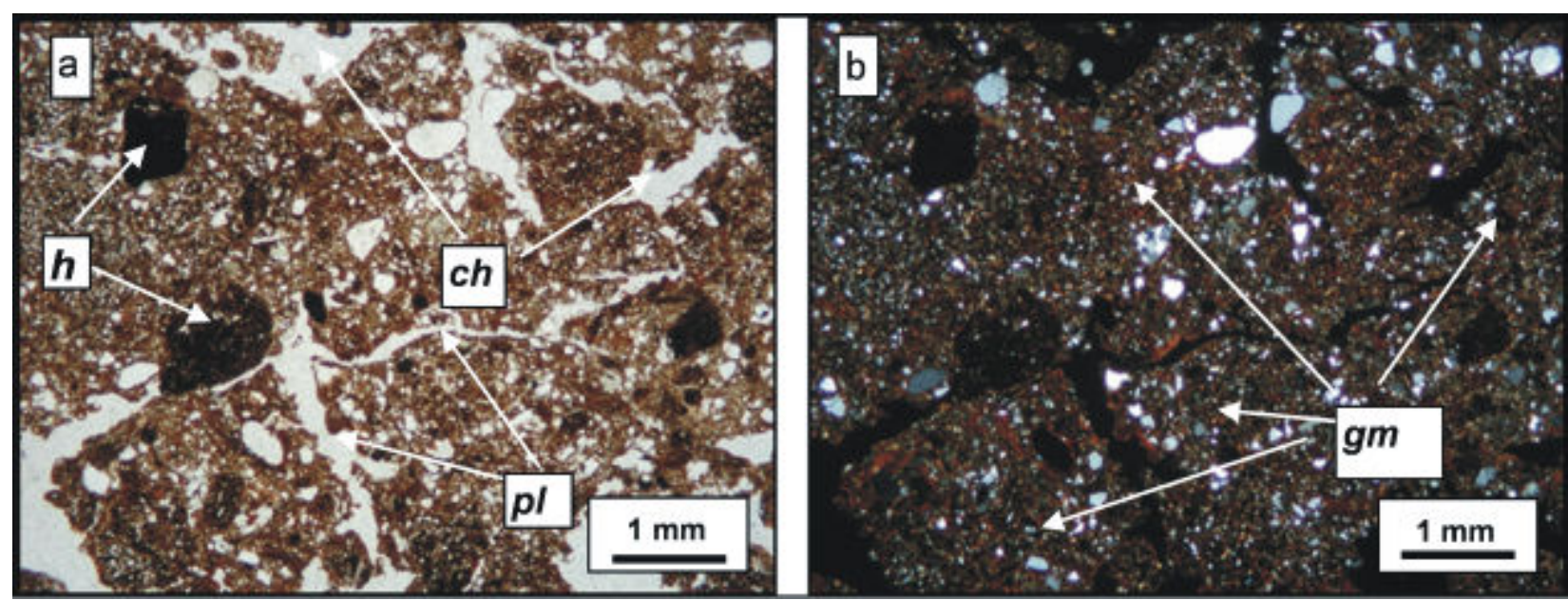

FIGURE 3. Typical micromorphological features in the soil developed from the Lower Triassic Buntsandstein clay. Pedon Bartków (pGC), horizon Bw: a - PPL, b - XPL. Groundmass $g m$ has properties inherited from the mudstones, $p l$ - planar voids, $c h$-chambers. Black opaque grains are hematite concretions $(h)$ 
planes have transformed into chambers developed from thin pores. Channels developed from the penetration of larger ones are rare.

Groundmass of the pBK clayey profile typically has properties derived from the parent rock. Microscopic observations indicate that the parent rock is not represented by pure clay, as suggested by geological data, but rather by clay mudstone. It generally comprises fine particles $(\mathrm{f}<0.02 \mathrm{~mm})$. Coarse components $(\mathrm{c}>0.5 \mathrm{~mm})$ are irregularly distributed, single grains of medium sand. The $\mathrm{c} / \mathrm{f}$ related distribution can be determined as open porphyric. The micromass is composed of quartz silt $\left(\mathrm{f}_{0.02 \mathrm{~mm}}\right)$ and clay minerals $\left(\mathrm{f}_{0.002 \mathrm{~mm}}\right)$ at a $1: 3$ ratio. Within the aggregates they form a compact background with a characteristic red-brownish colour (Fig. 3). The colour points to hematite admixture. Separation of clay domains is generally poor and an undifferentiated $b$-fabric prevails. Small clay aggregates in the form of staple speckled b-fabric are visible only sporadically. An interesting micromorphological feature is the high abundance of small (several millimetres in size) nodules. Their characteristic microscopic properties - an oval shape, a dark, almost black colour, and an insignificant transparency indicate that they are lithogenic structures (hematite pseudoolites), rather than soil ferruginous nodules. In the middle part of profile $\mathrm{pBK}$, distinct micromorphological pedogenic features are not present. Only the presence of depletion pedofeuters was noted. They are parts of the groundmass gradually brightening towards the aggregate margins, visible near large voids. Sporadically, thin clay coatings are observed on the walls of some voids. Organic remains in the form of plant or animal tissues are not present.
Sporadic bioturbations made by soil mesofauna occur in the upper part of horizon Bw, close to the boundary with horizon A.

Horizon Bw of soil developed from sandstones (in profile pGC) has different micromorphological properties. It has a typical intergrain mictroaggregate microstructure (Bullock et al. 1985) (Fig. 4). The main structural role is played by coarse components: coarse and medium sand-sized ( $>0.5 \mathrm{~mm})$. Between them occur small microaggregates of the fine fraction ( $\mathrm{f}>0.005 \mathrm{~mm}$ ). The $\mathrm{c} / \mathrm{f}$ related distribution is enaulic. Porosity is significantly high. The free voids between the microskeleton grains are simple packing voids or in places complex packing voids. Within the groundmass, the microskeleton is composed of poorly or medium rounded quartz grains. Sporadically, few opaque grains of hematite pseudoolites with a smooth outline are present. Fine particles generally have a small contribution. Analysis of microscopic optical features indicates that they include variably distributed clay minerals, hematite, and organic matter. They commonly form small aggregates that occasionally adhere to the margins of large grains (remains of the sandstone cement) (Fig. 4). The clay minerals do not form individual domains, due to which the fine fraction has an undifferentiated b-fabric. Red flaky hematite crystals are observed on some quartz grains. Micromorphological properties of pedogenic origin in horizon $\mathrm{Bw}$ of profile pGC have only organic metatubules (Brewer 1964). They are accumulations of organicmineral aggregates and fragments of poorly decomposed organic matter, loosely distributed in large voids between the sandstone fragments (Fig. 5).
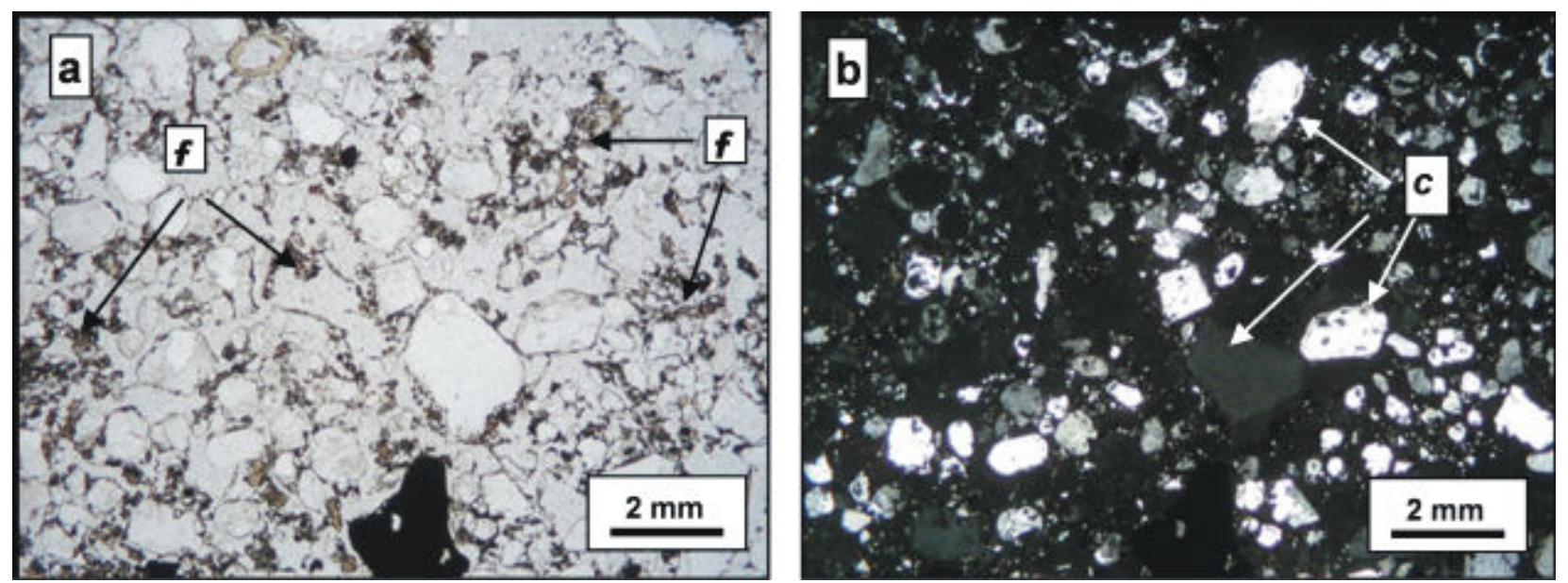

FIGURE 4. Typical micromorphological features in the soil developed from the lower Triassic Buntsandstein sandstone. Pedon Góra Czerwona, horizon Bw: a - PPL, $\mathrm{b}-$ XPL. An intergrain mictroaggregate microstructure. Groundmass consists of skeleton grains $c$ with fresh sharp edges and only a small amount of fine components $-f$. Enaulic $c / f$ distribution 

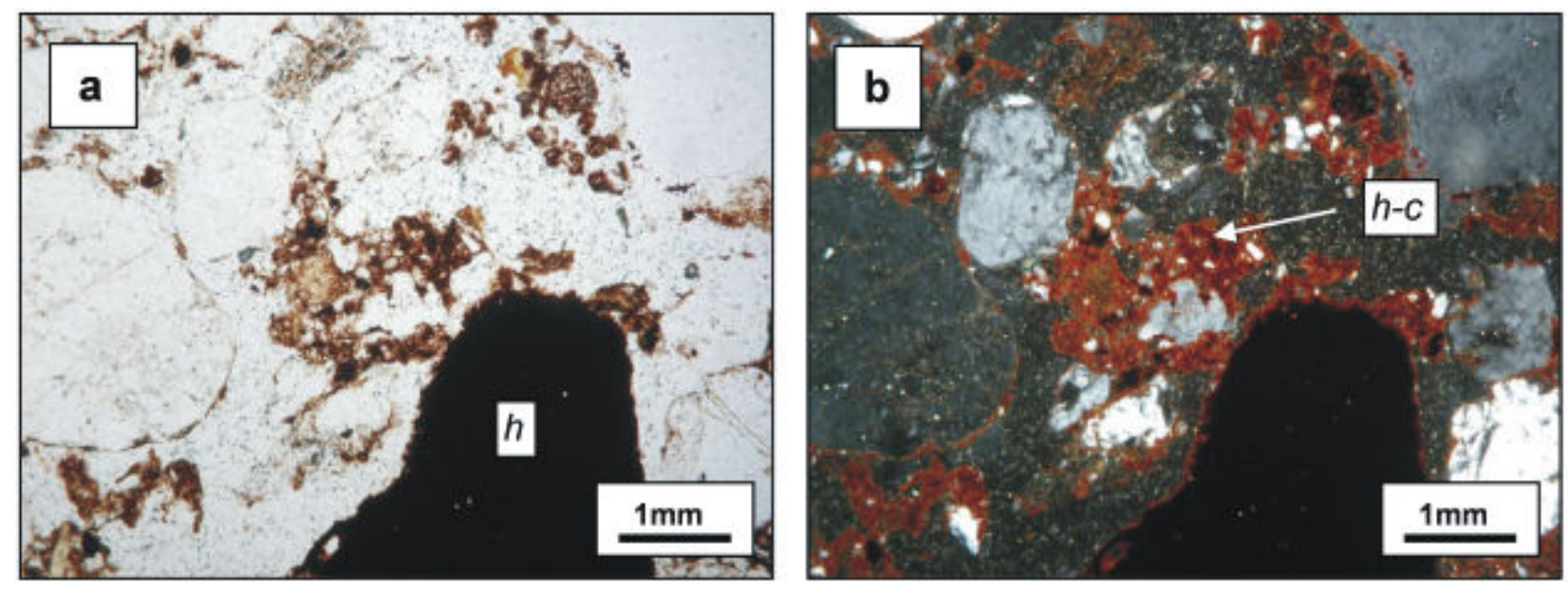

FIGURE 5. Hematite-clay microaggregates $(h-c)$ occurring between quartz grains. $h$ - hematite concretion. Pedon Góra Czerwona (pGC), horizon Bw: a - PPL, b - XPL

\section{Mineralogy}

The substrate of the studied soils contains all minerals that occur in the Lower Triassic rocks. The Góra Czerwona pedone (pGC) generally contains quartz and hematite. The diffractograms show reflections for quartz ( 4.26 and $3.33 \AA$ ) and hematite (2.69 and $1.48 \AA$ ) (Fig. 6). In the range for clay minerals, individual reflexes with values at $\mathrm{d}$ 7.18, 5.37, and $2.38 \AA$ point only to the presence of kaolinite.
Moreover, the presence of feldspars was observed as d $3.28 \AA$ reflexes (Fig. 6). In the Bartków pedone (profile $\mathrm{pBK}$ ) developed from clays, the mineralogical composition is similar throughout the entire profile. The main role is played by clay minerals and hematite. Quartz is an accessory but common component. Values $\mathrm{d}$ for reflexes $00 \mathrm{l}$ indicate the presence of chlorite -14.0 and $4.78 \AA$, illite $-10.0 \AA$, 4.48 and $3.33 \AA$, and kaolinite $7.15,5.37$ and $2.38 \AA$. Worth noting are the strong and sharp reflexes of these minerals in the

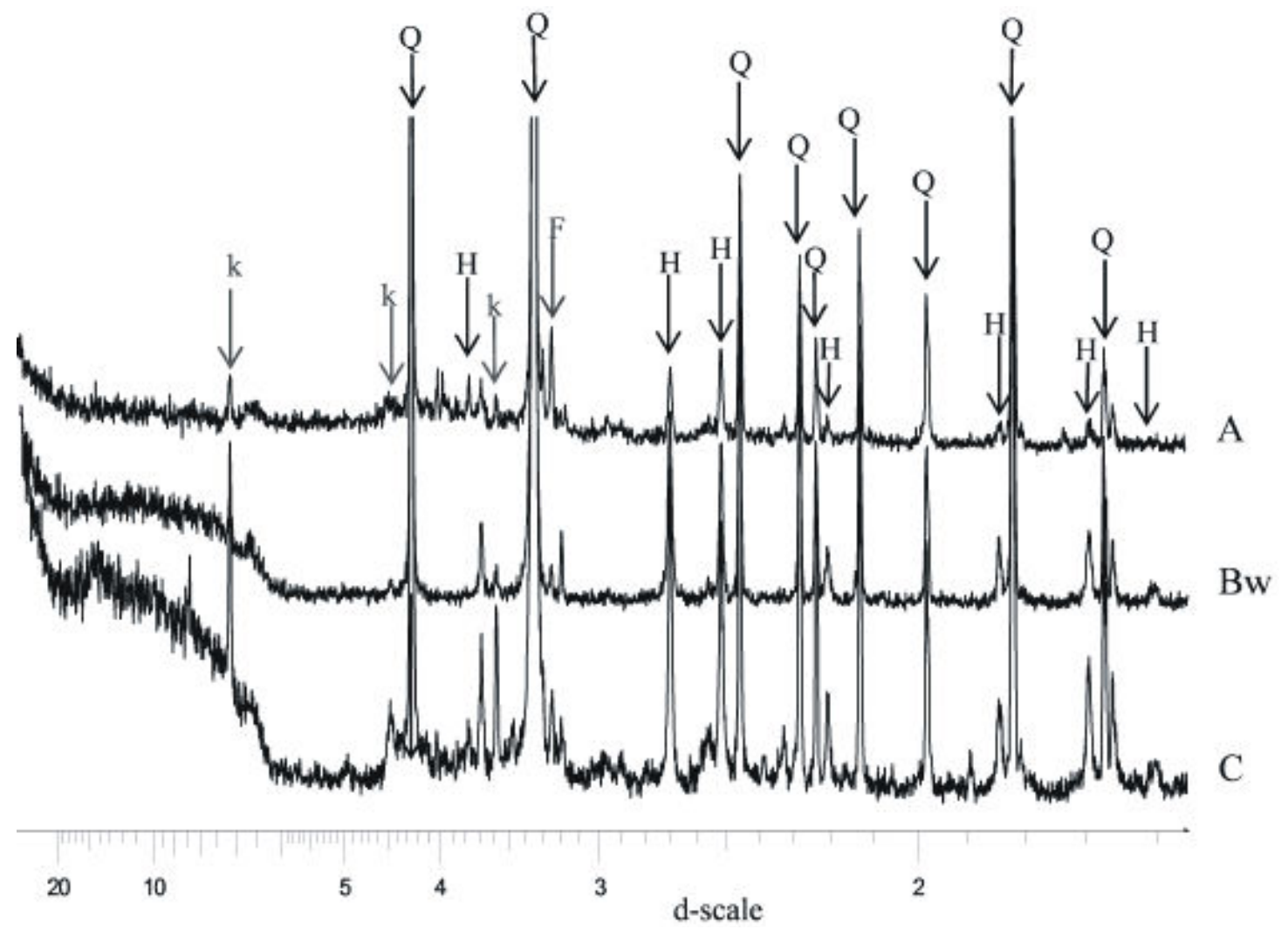

FIGURE 6. Mineralogical composition of the genetic horizons in pedon Góra Czerwona (pGC). XRD patterns of powder samples $<0.1 \mathrm{~mm}$. Symbols of minerals: $\mathrm{Q}$ - quartz, $\mathrm{H}$ - hematite, $\mathrm{k}$ - kaolinite. The d-scale in $\AA$ 
parent rock pointing to their good crystallization. In genetic horizons (A, Bw), the reflexes are less significant, which indicates their partial degradation by structure transformation. A reflex at about $12.0 \AA$ in horizon $\mathrm{Bw}$ indicates the presence of a mixed-layer chlorite/illite mineral (Fig. 7).

\section{Particle-size distribution}

The studied soils, being developed from two different parent rocks, have a significantly different particle-size distribution. The Bartków soil (pBK) developed from clays is a heavy (loam-clay) soil with a low amount of skeleton grains, whereas the Góra Czerwona soil (pCG) is a light (sandy) soil with abundant skeleton grains (Table 2).

Detailed analysis of the particle-size distribution in particular genetic horizons has indicated a characteristic variability in the contribution of some fractions. In profile $\mathrm{pBK}$ an increase of the content of clay and silt fractions is observed from the depth of about $20 \mathrm{~cm}$. The surficial horizons Ap have the particle-size distribution of sandy loams, whereas below, in horizons $\mathrm{Bw}, \mathrm{Bw} / \mathrm{C}$ and $\mathrm{C}$, respectively, occur sandy-clay loams, loams and clay loams (Table 2). The contribution of the sand fraction is also characteristic. The content

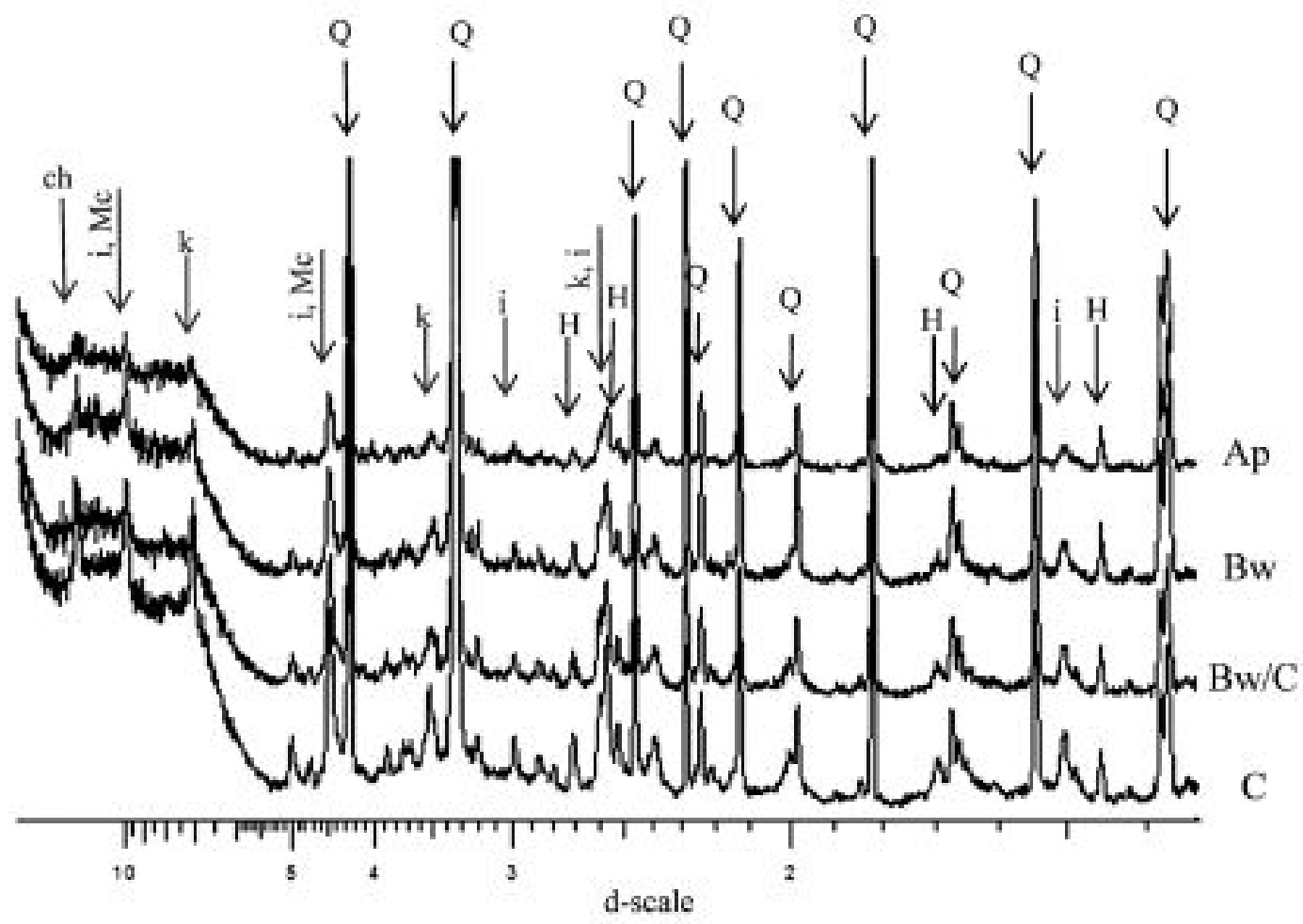

FIGURE 7. Mineralogical composition of the genetic horizons in pedon Bartków (pBK). XRD patterns of powder samples $<0.1 \mathrm{~mm}$. Symbols of minerals: Q - quartz, H - hematite, Mc - muscovite?, k - kaolinite, i - illite, ch - chlorite. The d-scale in $\AA$

TABLE 2. Particle-size distribution the soil developed from Lower Triassic sediments

\begin{tabular}{|c|c|c|c|c|c|c|c|c|c|c|c|c|c|}
\hline \multirow[t]{3}{*}{ Pedon } & \multirow[t]{3}{*}{ Horizon } & \multirow{3}{*}{$\begin{array}{l}\text { Depth } \\
\text { (cm) }\end{array}$} & \multicolumn{10}{|c|}{ Percentage of fraction (diameter in $\mathrm{mm}$ ) } & \multirow{3}{*}{$\begin{array}{l}\text { Textural } \\
\text { class* } \\
\text { (USDA) }\end{array}$} \\
\hline & & & \multirow{2}{*}{$\begin{array}{l}\text { Skele- } \\
\text { ton } \\
>2.0\end{array}$} & \multicolumn{9}{|c|}{ Fine earth $(100 \%)$} & \\
\hline & & & & $2.0-1.0$ & $1.0-0.5$ & $0.5-0.25$ & $0.25-0.1$ & $0.1-0.05$ & $0.05-0.02$ & $0.02-0.006$ & $0.006-0.002$ & $<0.002$ & \\
\hline \multirow[t]{4}{*}{$\mathrm{pBK}$} & Ap & $0-20$ & 4.8 & 1.6 & 9.9 & 16.5 & 27.0 & 12.0 & 8.0 & 8.0 & 5.0 & 12.0 & SL \\
\hline & $\mathrm{Bw}$ & $20-45$ & 1.0 & 0.5 & 5.4 & 5.1 & 19.0 & 10.0 & 9.0 & 8.0 & 21.0 & 22.0 & $\mathrm{~L}$ \\
\hline & $\mathrm{Bw} / \mathrm{C}$ & $50-60$ & 0.0 & 0.4 & 2.6 & 3.5 & 20.5 & 11.0 & 10.0 & 14.0 & 14.0 & 24.0 & $\mathrm{~L}$ \\
\hline & $\mathrm{C}$ & $60-70$ & 0.1 & 2.7 & 1.2 & 5.2 & 8.9 & 6.0 & 11.0 & 14.0 & 18.0 & 33.0 & $\mathrm{CL}$ \\
\hline \multirow[t]{3}{*}{ pCG } & A & $0-10$ & 6.7 & 5.8 & 14.2 & 28.5 & 26.4 & 5.0 & 7.0 & 6.0 & 1.0 & 6.0 & LS \\
\hline & $\mathrm{Bw}$ & $10-45$ & 16.9 & 2.7 & 14.5 & 26.0 & 19.7 & 13.1 & 8.0 & 9.0 & 2.0 & 5.0 & LScb \\
\hline & $\mathrm{C}$ & $45-60$ & 37.0 & 9.7 & 9.4 & 22.8 & 23.1 & 18.0 & 6.0 & 2.0 & 1.0 & 8.0 & Svst \\
\hline
\end{tabular}

*SL - sandy loam, L - loam, CL - clay loam, LS - loamy sand, LScb - cobbly loamy sand, Svst - very stony sand. 
of coarse sand rapidly decreases downwards from about $10 \%$ in horizon Ap to about $1 \%$ in horizon C. The content of fine and very fine sand in particular horizons of the middle part of the profile $\mathrm{pBK}(\mathrm{Bw}$ and $\mathrm{Bw} / \mathrm{C}$ ) is similar and reaches about $10 \%$.

In a very strong skeletal profile $\mathrm{pCG}$ the grain size of the fine earth $(<2.0 \mathrm{~mm})$ draws attention. It is very uniform (loamy sands) in the entire profile. The fractions are dominated by medium sand - from $28.5 \%$ (in horizon A) to $22.8 \%$ (in horizon C). A downward increase of the contribution of very fine sand, from 5\% (in horizon A) to 18\% (in horizon C), is a very characteristic feature. The content of silt fractions is the highest in the middle part of the profile - about $20 \%$ in horizon Bw. The clay fraction content is uniform in the entire profile at the level of several percent (Table 2).

\section{Physical-chemical and chemical properties}

Compilation of the basic physical-chemical and chemical properties of the soils can be found in Tables 3 and 4. Particular properties not only depend on the type of the parent rock but also on the habitat type and land use. This may be exemplified by the organic carbon (TOC) and nitrogen content. In the humus A horizon of the forest soil in Góra Czerwona (profile pGC), the TOC content exceeds $50 \mathrm{~g} / \mathrm{kg}^{-1}$, whereas the same horizon in arable soil from Bart-

TABLE 3. Chemical properties the soil developed from Lower Triassic sediments (part I)

\begin{tabular}{|c|c|c|c|c|c|c|c|c|}
\hline \multirow[t]{2}{*}{ Pedon } & \multirow{2}{*}{$\begin{array}{l}\text { Hori- } \\
\text { zon }\end{array}$} & \multirow{2}{*}{$\begin{array}{l}\text { Depth } \\
(\mathrm{cm})\end{array}$} & \multicolumn{2}{|l|}{$\mathrm{pH}$} & TOC & $N(t)$ & \multirow[t]{2}{*}{$\mathrm{C}: \mathrm{N}$} & \multirow{2}{*}{$\frac{\mathrm{Fe}_{2} \mathrm{O}_{3}}{(\%)}$} \\
\hline & & & $\mathrm{H}_{2} \mathrm{O}$ & $\mathrm{KCl}$ & $\left(\mathrm{g} \cdot \mathrm{kg}^{-1}\right)$ & & & \\
\hline \multirow[t]{4}{*}{$\mathrm{pBK}$} & $\mathrm{Ap}$ & $0-20$ & 5.9 & 5.0 & 10.9 & 0.12 & 9.08 & 2.32 \\
\hline & $\mathrm{Bw}$ & $20-45$ & 5.8 & 4.8 & 4.3 & 0.05 & 8.60 & 2.57 \\
\hline & $\mathrm{Bw} / \mathrm{C}$ & $50-60$ & 5.6 & 4.4 & 2.0 & 0.06 & 3.33 & 4.82 \\
\hline & $\mathrm{C}$ & $60-70$ & 5.3 & 4.1 & n.d & n.b & - & 6.89 \\
\hline \multirow[t]{3}{*}{$\mathrm{pCG}$} & $\mathrm{A}$ & $0-10$ & 3.4 & 2.4 & 51.6 & 0.21 & 24.57 & 2.09 \\
\hline & $\mathrm{Bw}$ & $10-45$ & 3.8 & 3.0 & 5.6 & 0.03 & 18.67 & 5.43 \\
\hline & $\mathrm{C}$ & $45-60$ & 4.1 & 3.6 & 2.9 & 0.01 & 29.00 & 4.44 \\
\hline
\end{tabular}

ków (pBK) contains only $10 \mathrm{~g} / \mathrm{kg}^{-1}$ of organic carbon. A small contribution of TOC was also noted deeper in profile pGC. The total nitrogen content $\left(\mathrm{N}_{t}\right)$ show the same trend as the TOC content. Worth noting is the difference in the $\mathrm{C}: \mathrm{N}$ ratio in the analysed profiles - in profile pCG it is much higher. Arable soil from Bartków (pBK) is acidic, whereas the forest soil from Góra Czerwona (profile pGC) is strongly acidic. Worth emphasizing is the low variability of $\mathrm{pH}$ values in $\mathrm{H}_{2} \mathrm{O}$ between particular genetic horizons in each of the profiles: from 5.9 (Ap) to $5.3(\mathrm{C})$ in profile $\mathrm{pBK}$, and from 3.4 (A) to 4.1 (C) in profile pCG.

The content of exchangeable aluminium (Alex) in both analysed soils is very interesting. In profile $\mathrm{pBK}$, the content of Alex is in a very wide range - from very low in horizon $\mathrm{A}$ (only $0.3 \mathrm{cmol}_{(+)} \mathrm{kg}^{-1}$ ) to very high in horizon $\mathrm{C}$ (exceeding $16 \mathrm{cmol}_{(+)} \mathrm{kg}^{-1}$ ). In profile pCG, the average contents of Alex is higher and has a different distribution. It reaches its maximum (above $11 \mathrm{cmol}_{(+)} \mathrm{kg}^{-1}$ ) in horizon A, whereas deeper the values are lower and rather levelled - about $5 \mathrm{cmol}_{(+)} \mathrm{kg}^{-1}$ in horizon $\mathrm{Bw}$ and $6.5 \mathrm{cmol}_{(+)} \mathrm{kg}^{-1}$ in the parent rock. Values of exchange acidity Hex+Alex) are strictly linked with the Alex content. Generally, in the entire profile pCG and the middle and lower horizons of profile $\mathrm{pBK}$, exchange acidity depends only on exchangeable aluminium.

The studied soils differ in their sorption properties. In certain genetic horizons of forest soil (pGC), values of potential acidity (Ha) significantly change with depth - from almost $20 \mathrm{cmol}_{(+)} \mathrm{kg}^{-1}$ in horizon A to $4 \mathrm{cmol}_{(+)} \mathrm{kg}^{-1}$ in horizon C. In arable soil (pBK) the Ha values increase with depth - from $3.14 \mathrm{cmol}_{(+)}$ $\mathrm{kg}^{-1}$ in horizon Ap to $6.62 \mathrm{cmol}_{(+)} \mathrm{kg}^{-1}$ in the basal horizon $\mathrm{C}$.

A very characteristic feature is the generally low content of base cations (BEC). It is particularly low in soil developed from sandstones (pGC) - from 0.94 $\mathrm{cmol}_{(+)} \mathrm{kg}^{-1}$ in horizon A to exceedingly low in the parent rock, only $0.04 \mathrm{cmol}_{(+)} \mathrm{kg}^{-1}$. In soil developed from clays (pBK), BEC reached higher values - from

TABLE 4. Chemical properties the soil developed from Lower Triassic sediments (part II)

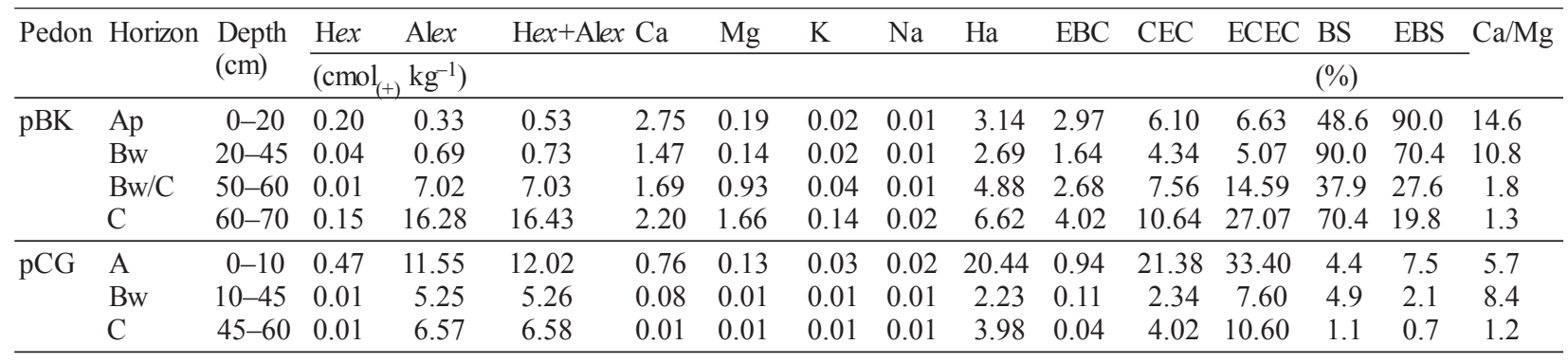

Hex - exchangeable acidity, Alex - exchangeable Al, Ha - potential acidity, EBC - exchangeable base cations, CEC - cation exchange capacity, ECEC - effective cation exchange capacity, BS - base saturation, EBS - effective base saturation. 
$4.02 \mathrm{cmol}_{(+)} \mathrm{kg}^{-1}$ in the parent rock to $2.97 \mathrm{cmol}_{(+)} \mathrm{kg}^{-1}$ in the horizon A. The contents of particular base cations depend on the genetic horizon of the studied soil. Generally, the $\mathrm{Ca}^{+2}$ cation prevails, whereas the values of $\mathrm{K}^{+}$and $\mathrm{Na}^{+}$are very low. In profile $\mathrm{pBK}$ the content of $\mathrm{Ca}^{+2}$ is between $2.75 \mathrm{cmol}_{(+)} \mathrm{kg}^{-1}$ in horizon $\mathrm{A}$ and $2.2 \mathrm{cmol}_{(+)} \mathrm{kg}^{-1}$ in horizon $\mathrm{C}$ of the parent rock, with a distinct minimum at $1.47 \mathrm{cmol}_{(+)} \mathrm{kg}^{-1}$ in the central part of the profile in horizon Bw. In profile pGC, the content of $\mathrm{Ca}^{+2}$ is significantly lower - only $0.76 \mathrm{cmol}_{(+)} \mathrm{kg}^{-1}$ in horizon $\mathrm{A}$ and almost trace values at $0.01 \mathrm{cmol}_{(+)} \mathrm{kg}^{-1}$ in horizon $\mathrm{A}$. In this soil, the content of $\mathrm{Mg}^{+2}$ is also low. In turn, in soil developed from clays, a distinct growth of $\mathrm{Mg}^{+2}$ values can be observed with depth to $1.66 \mathrm{cmol}_{(+)} \mathrm{kg}^{-1}$ in horizon $\mathrm{C}$ representing the parent rock.

Due to the specific red colour, determination of the iron content in the soil substrate was of crucial significance. The total content of iron is high in all genetic horizons. In profile $\mathrm{pBK}$ it varied from above $2 \%$ in horizon $\mathrm{A}$ to almost $7 \% \mathrm{Fe}_{2} \mathrm{O}_{3}$ in the parent rock. A higher content of iron in horizon $\mathrm{Bw}(5.43 \%$ $\left.\mathrm{Fe}_{2} \mathrm{O}_{3}\right)$ in comparison to the parent rock $(4.44 \%)$ is a characteristic feature in pedone pGC.

\section{DISCUSSION}

Of key significance for the soils developed from Lower Triassic Buntsandstein deposits in the Holy Cross Mountains is the precise determination of the role of lithogenic and pedogenic factors that resulted in their present-day stage of development. As evidenced by the analyses, the soils are characterized by very specific features and properties, therefore determination of their origin is a complex issue. This results from the fact that the main macroscopic and micromorphological features, mineralogical composition and physical-chemical properties largely depend on the very unique lithology of the parent rock (red beds), therefore the role played by pedogenic factors is not always clear (Blodgett et al. 1973). In consequence, it is difficult to find a sufficient number of proxies indispensable for determining diagnostic horizons, on which present-day soil classifications are based.

One of the most spectacular features observed in the Bartków and Góra Czerwona soils is their intensely red colour. Such red colour is rarely found in Polish soils. It was observed in the relict horizons of Rendzic Leptosol developed on the weathering terra rossa covers in the Polish Jura Chain (Zagórski 2003). In the Holy Cross Mountains, in areas with the occurrence of Lower Triassic rocks, red soil colour is well visible in the field - particularly on the surface of arable soils. The presence of red colour in soils is of high diagnostic significance. On the one hand, it testifies for the direct relationship between the mineral substrate and the parent rock, and on the other hand, it may be a proxy of the degree of pedogenic processes (Bigham and Ciołkosz 1993, Brzychcy et al. 2012). Red colour is also taken into account in many soil classifications. In the international soil classification WRB (IUSS Working Group WRB 2015), soils with colour in the range of about $10 \mathrm{R}$ according to the Munsell Colour Chart are referred to as Chromic.

In soil science literature, red colour is interpreted to be derived from the presence of hematite in the soil substrate (Torrent and Schwertmann 1986, Schwertmann 1993). The presence of hematite in the studied soils, suggested by the red colour, was explicitly evidenced by mineralogical analyses (Fig. 6 and 7). Data from XRD analyzes indicate that this mineral is not the product of current soil forming processes, but represents a typical lithogenic component, which was inherited from the parent rock. The presence of lithogenic hematite was also observed in soils developed from similar Triassic deposits in other parts of the Holy Cross Mountains (Zagórski and Kaczorek 2002). Mineralogical studies have also played an important role in assessing the role of allogenic material in the mineral substrate of the studied soils. Admixture of mineral material from deposits other than the Triassic (e.g. of Quaternary age) could be easily mask by the red colour. Similarity of the composition of clay minerals in particular genetic horizons is a proxy indicating that the soil substrate is derived from the transformation of parent rocks (sandstones or clays). Similar conclusions can be drawn from the particle-size distribution and micromorphological studies. The lithogenic uniformity of the soil profiles is of key significance in the interpretation of the properties of the analysed soils.

Soil structure is crucial for the recognition of pedogenic processes and identification of diagnostic horizons in the studied soils. Based on observations of macroscopic and micromorphological features, it can be concluded that the primary lithogenic structure of the parent rock was transformed into a new structure with pedogenic features. In surface horizons $A$, the structure is largely shaped by cultivation ( $\mathrm{pBK}$ ) or forest plant communities (pGC). Crucial indicators for the assessment of the pedogenesis is the structure that developed in the middle parts of the studied pedones - horizons $\mathrm{Bw}$ and $\mathrm{Bw} / \mathrm{C}$. The studies indicate that the main factors influencing the structure are climate conditions, such as seasonal freezing-thawing and wetting-drying cycles (Pires et al. 2008). These cycles through mechanical fragmentation cause gradual physical destruction of the parent rock - clay or sand- 

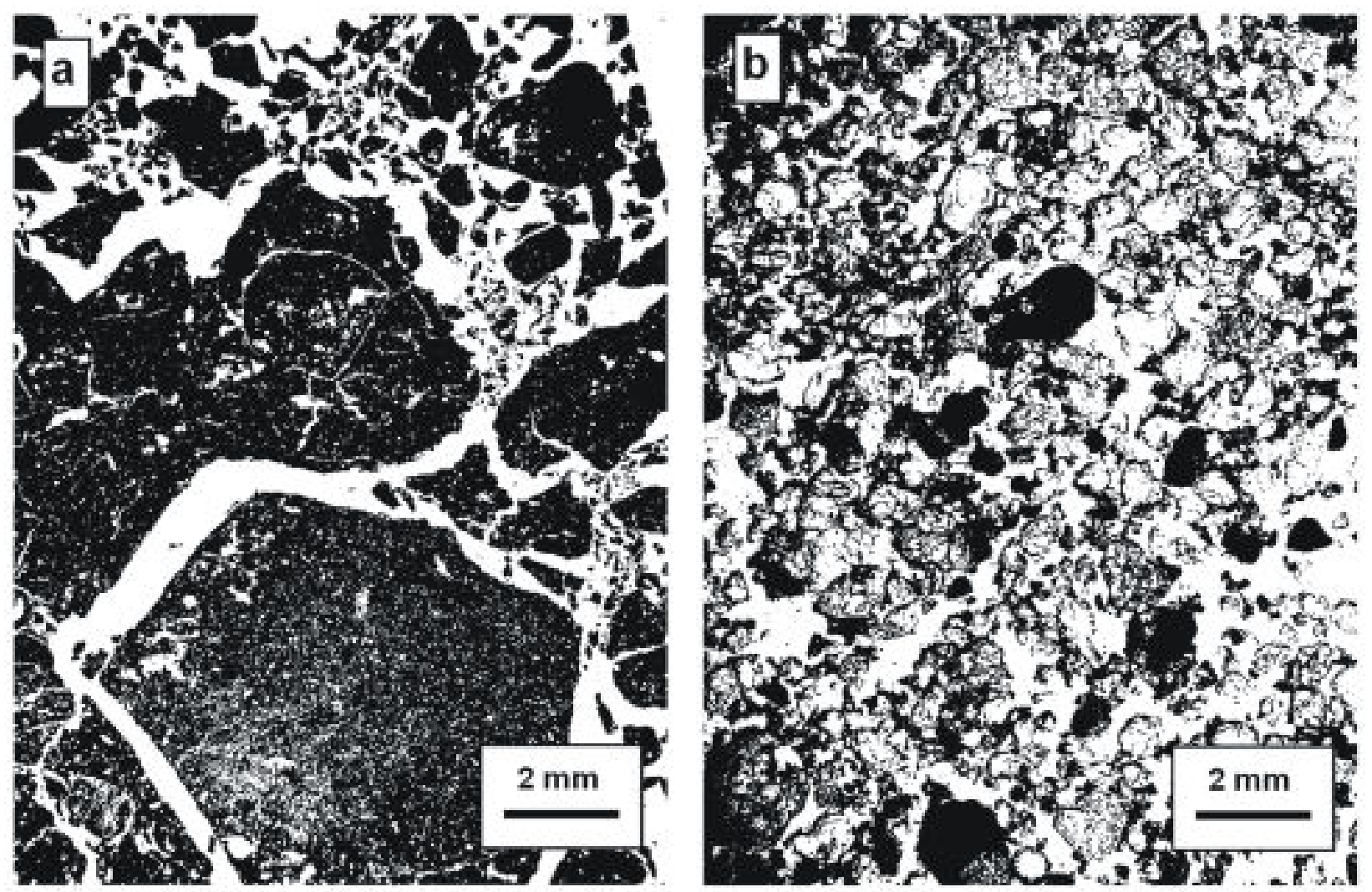

FIGURE 8. Examples of soil structure in the soils developed from the Lower Triassic Buntsandstein sediments: clays (a) and sandstone (b): $\mathrm{a}$ - The formation of angular blocky structures through the disintegration of clay bed. Pedon Bartków (pBK), horizon BwC. $b$ - The grain structure of the soil substrate formed from comminuted sandstone. Pedon Góra Czerwona (pGC), horizon Bw. Binary images (pores are white and the soil matrix is black)

stone (Fig. 8). Micromorphological analyses have indicated that the specific properties of the parent rock influence a particular type of structure. The presence of angular structure in soil developed from clays (profile pBK) is related to the geogenic susceptibility of Triassic clays to specific blocky fragmentation. This is evidenced by the specific void distribution as planes in form of an orthogonal network visible in microscopic observations. In turn, the grain structure occurring in soil developed from sandstones (profile pGC) is the result of low capability to secondary aggregation of grains derived from the destroyed rock. Microscopic analyses indicate that this is related not only to the low amount of the binding agent such as the colloidal fraction. The main reason is the insufficient dispersion of the clay-ferruginous fraction from the sandstone matrix. Microscopic observations indicate that fine fractions occurs as loose microaggregates, due to which smaller rock fragments and individual quartz grains are not bonded into soil aggregates. The few structural aggregates occurring in horizon $\mathrm{A}$, formed at the presence of organic matter, are not stable.

The studied soils are characterized by specific physical-chemical properties. Some of them strongly depend on the mineralogical properties of the substrate.
In the Góra Czerwona pedone (pGC), the particularly low cation exchange capacity (CEC) of the deeper genetic horizons (Table 4) depends not only on the low content of the clay fraction (5-8\%), but also on the fact that this fraction is dominated by two minerals with a low sorption activity - kaolinite and hematite. Interestingly, low CEC was also noted in the Bartków pedone, despite the high content of the colloidal fraction composed of clay minerals such as illite or chlorite. Usually, the sorption capacity in soils containing such minerals is much higher (Velde and Meunier 2008). According to some researchers, one of the factors restricting the sorption activity of the clay fraction may the presence of hematite nanocrystals on the packets of clay minerals (Stucki et al. 2012).

It seems that in the case of soils developed from Triassic red clays, the low ( $\mathrm{BS}<50 \%$ in $\mathrm{pBK}$ ) and very low (BS $<50 \%$ in pGC) contribution of alkaline cations to the sorption capacity (Table 4 ) of the studied soils depends on the mineral composition of the parent rocks and the low pedogenic advancement of the substrate weathering processes. In soil Góra Czerwona (profile pGC), the sandstones lack easily weathering minerals with alkaline metals (carbonates, phosphates), which could be the source of alkaline cations. In pedone 
Bartków (pBK), the contents of particular cations are shaped by two factors - rock type and soil management. The geochemistry of the parent rock influences the content of alkaline cations only in the lower parts of profile pBK - particularly in the parent rock. A similar content of the $\mathrm{Ca}^{2+}$ and $\mathrm{Mg}^{2+}$ cations is very characteristic. It is typical of clay rocks containing chlorites (Velde and Meunier 2008). In the upper genetic horizons, particularly in arable horizon A, the very wide range of the $\mathrm{Ca} / \mathrm{Mg}$ ratio indicates clear anthropogenic inference in the soil properties. Repeated cultivation over the years has depleted the soil in $\mathrm{Mg}$ and the applied fertilization (liming) did not balance the deficiency of this component.

Among the chemical properties of the analysed soils, a particular role is played by exchangeable aluminium. In both cases, the characteristically high exchangeable Al content should be related to the geochemical properties of the red bed-type rocks such as the Lower Triassic Buntsandstein deposits. According to Turner (1980), dry and hot climate conditions of aluminosilicate weathering result in the release of large quantities of mobile aluminium. Aluminium cations are sorbed by the clay fraction (Marques et al. 2002), and substituted into the hematite structure (Cornell and Schwertmann 2006). In the case of soil pGC, the variable content of exchangeable $\mathrm{Al}$ in the genetic horizons results from the fact that the source of $\mathrm{Al}$ includes both weathered hematite (particularly in horizon A) and the kaolinite structure. It seems that such high content of exchangeable $\mathrm{Al}$ in horizon $\mathrm{A}$ may be the relict of hematite disintegration under the influence of organic acids from the forest cover (Schwertmann 1991). The low stability of hematite in the acidic organic horizons of soils was pointed out by Schwertmann and Taylor (1989). In soil pBK, exchangeable $\mathrm{Al}$ is derived largely from clay minerals chlorite and illite. This is testified by its significantly high content in the parent rock. According to Marques et al. (2002), in terrestrial clay sediments, the aluminium cation is sorbed into the exchangeable position of mixed-layer 2:1 silicates, and during extraction with $1 \mathrm{M} \mathrm{KCl}$ results in high concentrations of exchangeable Al. The content of exchangeable $\mathrm{Al}$ is drastically inhibited in the upper part of soil pBK horizons $\mathrm{A}$ and $\mathrm{Bw}$ - through higher $\mathrm{pH}$ and presence of $\mathrm{Ca}^{2+}$ cations. Obviously, this may be related to the agricultural activities (e.g. liming) conducted on the soil. According to Nazarkiewicz and Kaniuczak (2012), fertilization and liming significantly influences the reaction and content of exchangeable $\mathrm{Al}$ in the surficial horizons of arable soils. Exchangeable Al plays a key role in shaping the values of diagnostic proxies: effective cation exchange capacity (ECEC) and effective base saturation (EBS). In soil developed from sandstones (pGC), the high content of Alex in relation to the alkaline cations results in the very low EBS value, which locates the soils among low fertility soils (dystric according to Polish Soil Classification 2011), hyperdystric according to WRB (IUSS Working Group WRB 2015). In the case of the Bartków soil, the decrease of exchangeable $\mathrm{Al}$ in the surficial horizons $\mathrm{A}$ and $\mathrm{Bw}$ results in a high value of EBS, accepted for high fertility soils (eutric according to WRB).

Specific physical-chemical properties of the studied soils are also related to their acidic reaction and potential acidity. Acidity is generally related to the mineralogy and geochemistry of the parent rocks completely depleted of carbonate components. Most probably external factors may also influence soil reaction. In the case of forest soil pGC, acidity may result from flow under the trees caused by rainfall (Kozłowski and Adwent 2011). In turn, in arable soil pBK, beside agricultural activities, deacidification takes place by accumulation of atmospheric silt rich in $\mathrm{Ca}$. Increased deposition of alkaline silts derived from the cement industry has been observed in the Holy Cross Mountains (Świercz 2006, Kozłowski 2012).

An interesting feature of the studied soils is the presence of organic carbon in deeper genetic horizons, even in the parent rock. This results from the terrestrial origin of the Triassic deposits. Organic matter in the form of plant detritus has been detected in them (Marynowski et al. 2006). This feature should be taken into account in assessing some diagnostic proxies (e.g. $\mathrm{C}: \mathrm{N}$ ) in soils developed from Lower Triassic rocks in the Holy Cross Mountains.

Summing up, the obtained results indicate that the studied soils belong to soils with specific advancement of soil processes. Table 5 shows the main properties, which can be used in the classification of soils. Significant transformation of the parent rock caused by physical factors is a pedogenic process. The processes have led to the development of a different soil substrate, with features typical of cambic horizons. The developed soil substrate is a specific substrate for the development of arable and forest plant communities (Gruba et al. 2015).

Based on the obtained results, we have attempted to assign the analysed soils based on criteria in the PSC (2011) and the international FAO-WRB soil classification (IUSS Working Group WRB 2015). The Bartków profile (pBK) representing soils developed from Lower Triassic clays has an Ap, Bw, Bw/C, C sequence of genetic horizons and fulfils the criteria for typical dystrophic brown soils (BDt). In the WRB classification, this soil is a Endoeutric Chromic 


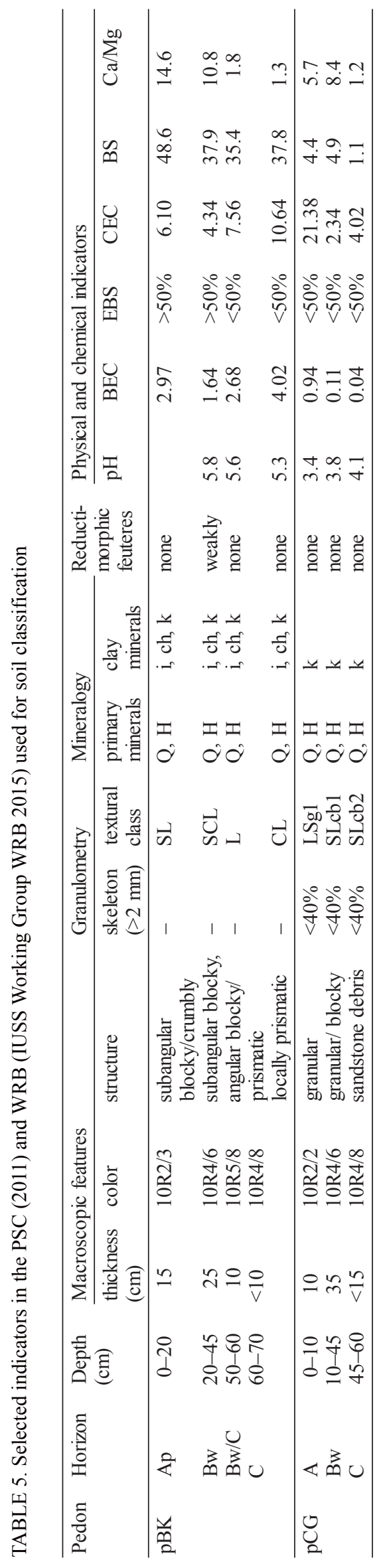

Cambisols (Loamic). Soils developed from Triassic red sandstones (Góra Czerwona, profile pGC) may be classified as humus dystrophic brown soil (BDpr) (PSC 2011) or according to the Classification of Forest Soils in Poland (KGLP 2000) as acidic brown soil (BRk). In the WRB (IUSS Working Group WRB 2015), this soil can be classified as Epidystric Chromic Endoleptic Cambisols.

\section{CONCLUSIONS}

1. Sandstones and clays of the Lower Triassic occurring on the surface of the terrain in the NW part of the Holy Cross Mountains (Poland) are interesting parent rocks soils. The resulting soil have considerable specificity properties that are not found in other soils on adjacent areas.

2. The red color of the soil substrate is a specific macroscopic feature of the soils developed from the Lower Triassic deposits. It is the result of the presence of hematite. Hematite was inherited from the rocks Buntsandstein that belong to the continental formations named as red beds.

3. The soils developed from the Lower Triassic sediments are poor in nutrients. These include the type of dystrophic soils. Their chemical properties such as CEC, BSE, and $\mathrm{pH}$ are determined by mineralogical and petrographic features of soil substrate, which are inherited from the parent rock. The impact of current use - crops or forest community is noted in surface horizons.

4. The cambic horizon is diagnostic in soils developed from the Lower Triassic Buntsandstein deposits. As a sign of pedogenesis taken significant transformation of parent rock by climatic conditions, especially seasonal cycles of freezing-thawing and wetting-drying. The lithogenic primary rock structure has been changed in the new pedogenic one. Blocky structure was created in the clays and grainy structure in soils developed from sandstones.

5. Soils developed from the Lower Triassic Buntsandstein clays have a sequence of genetic horizons: $\mathrm{Ap}, \mathrm{Bw}, \mathrm{Bw} / \mathrm{C}, \mathrm{C}$ and fulfills the criteria assigned soils brown dystrophic typical (BDt) in the PSC (2011), whereas in the classification WRB identified as Endoeutric Chromic Cambisols (Loamic). Soils developed from the Lower Triassic Buntsandstein red sandstone can be classified as dystrophic brown soil humus (BDpr) in the PSC (2011). Within the soil classification WRB that soil can be assigned to Epidystric Chromic Endoleptic Cambisols. 


\section{ACKNOWLEDGMENTS}

Research was supported by the Polish Ministry of Science and Higher Education, project No. 2P04G10728.

\section{REFERENCES}

Barczuk A., 1979. Petrographic study of the Buntsandstein sediments from the North-Eastern border of the Holy Cross Mts (Central Poland). Archiwum Mineralogiczne 35 (2): 87155 (in Polish with English summary).

Bigham J.M., Ciołkosz E.J., 1993. Soil Color. Soil Science Society of America, Special Publication 31, Wiley, Madison: $159 \mathrm{pp}$.

Blodgett R., Crabaugh J., McBride E., 1973. The color of red beds a geologic perspective. [In:] Soil Color (Bigham J.M., Ciołkosz E.J., Editors). Soil Science Society of America, Special Publication 31, Wiley, Madison: 127-159.

Brewer R., 1964. Fabric and mineral analysis of soils. John Wiley\& Sons, New York: 470 pp.

Brindley G.W., Brown G., 1980. Crystal structures of clay minerals and their x-ray identification. Mineralogical Society, London: $494 \mathrm{pp}$.

Brzychcy S., Zagórski Z., Sieczko L., Kaczorek D., 2012. Analysis of groundmass colour as a tool for evaluating the extent of pedogenic processes in Chromic soils. Roczniki Gleboznawcze - Soil Science Annual 63(3): 3-7.

Bullock P., Fedoroff N., Jongerius A., Stoops G., Tursina T., 1985. Handbook for soil thin section description. Waine Research Publications. Wolverhampton, UK: $152 \mathrm{pp}$.

Cornell R.M., Schwertmann U., 2006. The iron oxides: structure, properties, reactions, occurrences and uses. Wiley-vch\&Co, Weinheim: 703 pp.

Filonowicz P., 1973. Explanations to the Detalied Geological Map of Poland 1:50 000, sheet Kielce. Instytut Geologiczny, Warszawa: $72 \mathrm{pp}$.

Filonowicz P., 1979. Explanations to the Detalied Geological Map of Poland 1:50 000, sheet Skarżysko Kamienna. Instytut Geologiczny, Warszawa: $71 \mathrm{pp}$.

Gruba P., Socha J., Błońska E., Lasota J., 2015. Effect of variable soil texture, metal saturation of soil organic matter (SOM) and tree species composition on spatial distribution of SOM in forest soils in Poland. Science of the Total Environment, 521: $90-100$.

Hanlie H., Yansheng G., Ke Y., Kexin Z., Zhaohui L., 2010. Red soils with white net-like veins and their climate significance in south China. Geoderma 160: 197-207.

IUSS Working Group WRB, 2015. World Reference Base for Soil Resources 2014, update 2015. International soil classification system for naming soils and creating legends for soil maps. World Soil Resources Reports No. 106. FAO, Rome: pp. 192.

Jahn R., Blume H.P., Asio V.B., Spaargaren O., Schad P., 2006. Guidelines for soil description. Roma FAO: $110 \mathrm{pp}$.

Kabała C., Czępińska-Kamińska D., Drewnik M., Jankowski M., Marzec M., 2014. Przewodnik do opisu profilu glebowego (Guidebook for soil profile description), in press. Polish Society of Soil Science: 74 pp. (in Polish).
Kacprzak A., Szymański W., Wójcik-Tabol P., 2015. The role of flysch sandstone in forming the properties of cover deposits and soils - examples from the Carpathians. Zeitschrift fur Geomorfologie 5, Supplement 1: 227-245.

Karczewska A., Kabała C., 2005. Metodyka analiz laboratoryjnych gleb i roślin (Methodology of soil and plants laboratory analyses), $4^{\text {rd }}$ editon. Akademia Rolnicza, Wrocław: pp.45 (in Polish).

Klasyfikacja Gleb Leśnych Polski, 2000. Centrum Informacyjne Lasów Państwowych: 122 pp.

Klatka T., 1965. Geomorphology of the Świętokrzyskie Mountains. Roczniki Gleboznawcze - Soil Science Annual 15: 129-162 (in Polish with English summary).

Kleczkowski A., 1970. Iron ores in the Bunter deposits of the northern margins of the Góry Świętokrzyskie. Prace Muzeum Ziemi 15(1): 193-221.

Kozłowski R., Adwent E., 2011. Spatial variability of selected physico-chemical soil properties in the central part of the Świętokrzyskie (Holy Cross Mountains). Monitoring Środowiska Przyrodniczego, Kieleckie Towarzystwo Naukowe 12: 93-101 (in Polish with English summary).

Kozłowski R., 2012. Influence of cement-lime industry on the physico-chemical properties of precipitation in a „Białe Zagłębie" region. Monitoring Środowiska Przyrodniczego 13: 63-70 (in Polish with English summary).

Lesovaya S.N., Goilo E.A., Chizhikova N.P., 2005. Mineralogical composition of red-Earth deposits and its effect on soil formation in the northern Taiga of European Russia. Eurasian Soil Science 38(8): 887-896.

Lindner L., 1971. Pleistocene stratigraphy and palaeogeomorphology of the north-western margin of the Holy Cross Mountains, Poland. Studia Geologica Polonica 35: 1-113 (in Polish with English summary).

Marques J., Teixeira W., Schulze D., Curi N., 2002. Mineralogy of soils with unusually high exchangeable $\mathrm{Al}$ from the western Amazon Region. Clay Minerals 37(4): 651-661.

Marynowski L., Wyszomirski P., Kurkiewicz S., 2006. The characteristics of organic matter from the Triassic clays of nw margin of the Holy Cross Mts (Poland) - preliminary report. Mineralogia Polonica 37(2): 117-126.

Nazarkiewicz M., Kaniuczak J., 2012. The effect of liming and mineral fertilization on the reaction, hydrolitic acidity, exchangeable acidity and content of exchangeable aluminium in Haplic Luvisols. Roczniki Gleboznawcze - Soil Science Annual 63(1): 43-48 (in Polish with English summary).

Oyama M., Takehara H., 1970. Revised standard soil color charts (RSSCC), Research Council for Agriculture, Forestry and Fisheries, Japan.

Pires L.F., Cooper M., Cássaro F.A.M., Reichardt K., Bacchi O.O.S., Dias N.M.P., 2008. Micromorphological analysis to characterize structure modifications of soil samples submitted to wetting and drying cycles. Catena72(2): 297-304.

Polish Soil Classification (Systematyka gleb Polski), 2011. Roczniki Gleboznawcze - Soil Science Annual 62(3): 1-193 (in Polish with English summary).

Schwertmann U., 1991. Solubility and dissolution of iron-oxides. Plant and Soil 130: 1-25.

Schwertmann U., 1993. Relations between iron oxides, soil color and soil formation. [In:] Soil Color (Bigham J.M., Ciołkosz E.J., Editors), Soil Science Society of America, Special Publication 31, Wiley, Madison: 51-69. 
Schwertmann U., Taylor R.M., 1989. Iron oxides. [In:] Minerals in soil Environments (J.B. Dixonand, S.B. Weed, Editors) Soil Science Society of America, Madison, Wisconsin, USA: 379438.

Senkowiczowa H., 1966. Influence of palaeozoic structure and of morphology of the Święty Krzyż Mts. area upon the development of Triassic deposits. Kwartalnik Geologiczny 10(4): 986-1002 (in Polish with English summary).

Senkowiczowa H., Ślączka A., 1962. The Bunter on the Northern Border of the Holy Cross Mts. Roczniki Polskiego Towarzystwa Geologicznego 32 (3): 313-337 (in Polish with English summary).

Skłodowski P., Maciejewska A., 1986. Trace elements in rusty soils developed from triassic sandstones, Roczniki Gleboznawcze - Soil Science Annual 37(1): 67-78 (in Polish with English summary).

Sokołowski S., Cieśliński S, Czermański J., 1973. Geological structure of Poland, Vol. 1 Stratigraphy, Part 2 Mesozoic, Wydawnictwa Geologiczne, Warszawa: 56-63 (in Polish).

Stoops G., 2003. Guidelines for analysis and description of soil and regolith thin section. Soil Science Society of America, Madison, Wisconsin, USA: 184 pp.

Stoops G., Marcelino V., Mees F., 2010. Interpretation of Micromorphological Features of Soils and Regoliths. Elsevier, Amsterdam: $752 \mathrm{pp}$.

Stucki J.W., Goodmann B.A\& Schwertmann U., 2012. Iron in soils and clay minerals vol. 217. Springer Science \& Business Media.

Szafranek A., 1989. The effect of the area relief and the parent rock on formation of soils developed from Devonian and Triassic sandstones of the Świętokrzyski region. Roczniki Gleboznawcze - Soil Science Annual 40(2): 59-81(in Polish with English summary).

Szafranek A., 1990. Effect of area relief and parent rock on development of soils from Devonian and Triassic sandstones of the Świętokrzyski region. Part II. Chemical properties of soils. Roczniki Gleboznawcze - Soil Science Annual 41(3/4): 157177 (in Polish with English summary).

Szafranek A., Skłodowski P., 2006. Properties of acid brown soils developed from sandstones of the Świętokrzyskie Region. Polish Journal of Soil Science 39(1): 65-71.
Świercz A., 2006. Suitability of pine bark to evaluate pollution caused by cement-lime dust. Journal of Forest Science 52: 93-98.

Torrent J., Schwertmann U., 1986. Influence of hematite on the color of red beds. Journal of sedimentary petrology 57(4): 682-686.

Turner P., 1980. Continental red beds. Elsevier, Amsterdam: 561 pp.

Velde B.B. Meunier A., 2008. The origin of clay minerals in soil and weathered rock. Springer Science \& Business Media: 405 pp.

Vodyanitskii Y.N., Goryachkin S.V., Lesovaya S.N., 2003. Iron oxides in burozems on red-colored deposits in European Russia and the color differentiation of soils. Eurasian Soil Science 36(11): 1145-1158.

Zagórski Z., 2003 Mineralogical and micromorphological indicators of the origin and properties of rendzina soils developed from carbonate rocks of different geological formations. Fundacja Rozwój SGGW. Warszawa, Poland: 124 pp (in Polish with English summary).

Zagórski Z., Brzychcy S., 2009: Kaolinite as an indicator of lithogenetic process in soils developed from lower Triassic sediments in the Holly Cross Mountains. Roczniki Gleboznawcze - Soil Science Annual 60(4): 104-112 (in Polish with English summary).

Zagórski Z., Kaczorek D., 2002. Haematite - a lithogenic form of iron in soils from the southern part of the Holy Cross Mountains. Annals of Warsaw Agricultural University SGGW, Agriculture 43(200): 17-24.

Zagórski Z., Kisiel M., 2010. Lepidocrocite as mineralogical indicator of gley processes in soils formed on Lower Triassic sediments in the Holy Cross Mountains. Roczniki Gleboznawcze - Soil Science Annual 61(1): 77-87 (in Polish with English summary).

Zagórski Z., Kisiel M., 2014: Soils developed from red clays of the Lower Triassic in the north-western part of the Świętokrzyskie Mountains [In:] Soil sequences atlas (Świtoniak M., Charzyński P., Editors), Wydawnictwo Uniwersytetu Mikołaja Kopernika, Torun: 141-153.

Received: January 26, 2016

Accepted: February 29, 2016

\section{Niektóre właściwości i pozycja systematyczna gleb wytworzonych $\mathrm{z}$ czerwonych piaskowców i ilów dolnego triasu w NW obrzeżeniu Gór Świętokrzyskich}

Streszczenie: Celem badań było porównanie właściwości gleb wytworzonych z osadów dolnego triasu (pstry piaskowiec) w północno-zachodniej części Gór Świętokrzyskich (Polska). Są to osady o genezie kontynentalnej i unikalnych właściwościach, określane jako red beds. Do szczegółowych analiz zostały wybrane dwa reprezentatywne pedony glebowe - profil Bartków (pBK) wytworzony z iłu i profil Góra Czerwona (pGC) wytworzony z piaskowca. Zbadano morfologię profili, cechy mikromorfologiczne, skład mineralny oraz właściwości fizykochemiczne. Większość właściwości gleb jest konsekwencją pierwotnej litologii skały macierzystej. Specyficzną cechą morfologii gleb jest obecność czerwonych barw (około $10 \mathrm{R}$ w skali barw Munsella) związanych z obecnością hematytu. Jak wynika z danych XRD hematyt nie jest produktem obecnych procesów glebotwórczych, ale jest litologicznym składnikiem, który został odziedziczony ze skały macierzystej. Pod wpływem czynników klimatycznych pierwotna struktura skał została przekształcona w nową pedogeniczną. Gleby wytworzone z iłów mają charakterystyczną foremnowielościenną ostro- 
krawędzistą strukturę. Analiza mikromorfologiczna wykazała, że ważną rolę w tworzeniu struktury gleby ma geogeniczna podatność iłów triasowych do kostkowego rozpadu. Wskazuje na to widoczny w szlifach system cienkich porów tworzących prostokątną sieć. Gleby wytworzone z piaskowca mają słabą (niestabilną) strukturę foremnowielościenną zaokraggloną. Głównym tego powodem jest niewystarczająca dyspersja frakcji ilasto-żelazistej pochodzącej ze spoiwa piaskowca. Obserwacje mikroskopowe pokazują, że frakcje drobne występują jako luźne mikroagregaty, co powoduje, że małe fragmenty skały i pojedyncze ziarna kwarcu nie są wiązane w agregaty glebowe. Badane gleby charakteryzują się specyficznymi właściwościami fizykochemicznymi. Niektóre z nich w dużym stopniu zależą od mineralogicznych właściwości substratu glebowego. Silne zakwaszenie (pH 3-4) i bardzo niska zawartości kationów zasadowych (poniżej $1,0 \mathrm{cmol}_{(+)} \cdot \mathrm{kg}^{-1}$ ), występuje ze względu na brak w piaskowcach minerałów węglanowych i słabego wietrzenia glinokrzemianów. Wysoka zawartość Al wymiennego w ile $\left(16,5 \mathrm{cmol}_{(+)} \cdot \mathrm{kg}^{-1}\right)$ wiąże się z geochemicznymi właściwościami skał typu red beds, jakimi są osady dolnego triasu (pstrego piaskowca). Gleby wytworzone z czerwonych iłów dolnego triasu (pstrego piaskowca) mają sekwencję poziomów genetycznych A, Bw, Bw/C, C i spełniają kryteria wyznaczone dla dystroficznych gleb brunatnych typowych (BDt) w Systematyce gleb Polski (SgP 2011), natomiast w WRB zostały sklasyfikowane jako Endoeutric Chromic Cambisols (Loamic). Gleby wytworzone z czerwonych piaskowców dolnego triasu (pstrego piaskowca) można sklasyfikować w SgP (2011) jako dystroficzne gleby brunatne próchniczne (BDpr). W klasyfikacji WRB, gleby te można przypisać do Epidystric Chromic Endoleptic Cambisols.

Stowa kluczowe: Trias (pstry piaskowiec), czerwone iły i piaskowce, mikromorfologia gleb, mineralogia gleb, właściwości gleb, Góry Świętokrzyskie, Polska 